\title{
IDENTIFICATION OF TEAK MISTLETOE SPECIES AND BASIC INFORMATION OF UTILIZATION AS MEDICINAL PLANT
}

\author{
Zainal Muttaqin ${ }^{1 *}$, Sri Wilarso Budi $\mathbf{R}^{2}$, Basuki Wasis ${ }^{2}$, Iskandar Z Siregar ${ }^{2}$, and Corryanti ${ }^{3}$ \\ ${ }^{1}$ Student of Doctor program at Silviculture Tropical Mayor, Forestry Faculty, Bogor Agricultural University \\ Kampus IPB Darmaga PO BOX 168 Bogor West Java 16001, Indonesia \\ ${ }^{2}$ Department of Silviculture, Faculty of Forestry, Bogor Agricultural University \\ Kampus IPB Darmaga PO BOX 168 Bogor West Java 16001, Indonesia \\ ${ }^{3}$ Development and research Center of Perum Perhutani \\ Jl. Wonosari Batokan PO BOX 6 Cepu Center Java 58302, Indonesia \\ *Corresponding author: znldeg@yahoo.com
}

\begin{abstract}
Mistletoe is hemiparasitic plants (macroparasite) on seasonal and annual plants include trees, however, mistletoes are also beneficial as key species that fill in the ecological niche, and a potential to non-wood forest product such as medicinal plants as one of them. The objectives of this research are to identify species of teak mistletoes at Padangan Clonal Seed Orchard (CSO) in Perum Perhutani and to aim its posibilities as medicinal plant. The inventory methods on species of teak mistletoes was carried out in compartements/blocks of teak clones that are designated as Observation Sample Plots (OSPs/PCP) of the attack intensity from low, medium, high, control; and four units Observation Measurement Plots (OMPs/PUP) on each OSPs/PCP. Continously, it was analized by comparing the same species of mistletoes on other host trees as reference which was efficacious to be used as medicinal plant. Three species of mistletoes parasitizing teak clone stands were identified as Dendrophthoe pentandra (L.) Miq. of family of Loranthaceae which is also attacking other host trees, Macrosolen tetragonus (Blume) Miq. of family of Loranthaceae too, Viscum articulatum Burm. F. of family of Santalacea/Viscaceae that is hyperparasite on two other mistletoes. The comparison with the same teak mistletoe but on different host trees shows that including $D$. pentandra and $V$. articulatum have the potential for hypertension treatment. D. pentandra is used too for medicine to cure ilness, wounds, fester and recovery from parturition. Known that chemical content this mistletoe comprise of flavonoid ingrident, fenolat acid (terulat acid, para hidroksi benzoate acid, kumarat acid, protokatekuat acid and vanilat acid. As for the utilization of M. tetragonus hasn't been discovered up to this moment.
\end{abstract}

Key words: mistletoe, identification, teak clone, non-wood forest product, medicinal plant

\section{INTRODUCTION}

Mistletoe has not yet reached offensive explosion (outbreak). Parasite attack data ranged from 10.7 to 49.6\%; covering 650.3 ha of 144 trees clones. The numbers of attacked trees (17 338 trees) showed almost $1 / 3$ (one third) of total existing trees (59 944 trees). The purpose of this research are: 1) to identify species of teak mistletoe based of morphology character especially variety of leaf, 2) to analyze basic data relating of potential usage teak mistletoe as medicinal plant.

\section{MATERIAL AND METHOD}

\section{Materials and Instruments}

Materials used include: mistletoe attacking map of Padangan CSO 1 : 13000 scale; alcohol $70 \%$ and cutton, newspaper, plastic $40 \times 60 \mathrm{~cm}$ size for making herbarium, etc. Instruments used include: compass, GPS Garmin Oregon 550, altimeter, binokuler, etc.

\section{Time and Location}

Field research will be carried out in compartements of teak forest in CSO Padangan, defined as PCP consisting of and PUP's (50 x 50 metre size) amount of 4 (four) that are placed and spread in PCP refer to EFForTS/CRC990 (2012). Before, those plots were made by Muttaqin (2014); research conducted for 10 months from September 2014 until June 2015.

\section{Research Procedures}

\section{(1). Identify mistletoe species}

At every PUP amount of 12 PUP, chosen only one specimen of one mistletoe species that have good feature, so there were 12 specimens. On every mistletoe species that founded, observe directly morphology characteristics and suite with book reference of mistletoe identification such as Flora Malesiana Series I-Seed Plants Volume 13 -1997 Loranthaceae dan Viscaceae; and Flora of Java Volume 2-1965. For species identification more detail, so take specimen herbarium sample which of parts were preserved in alcohol $70 \%$, further for identification in Herbarium Bogoriense, Biology Research Center-LIPI, Bogor. 
Table 1. Leaf morphology characteristics D.pentandra and M. tetragonus

\begin{tabular}{|c|c|c|c|c|c|c|c|c|c|c|c|c|c|c|c|}
\hline No & $\begin{array}{c}\text { Mistletoe } \\
\text { species }\end{array}$ & $\begin{array}{l}\mathrm{LL} \\
(\mathrm{cm})\end{array}$ & $\begin{array}{l}\text { STL } \\
(\mathrm{cm}) \\
\end{array}$ & $\begin{array}{l}\mathrm{LW} \\
(\mathrm{cm})\end{array}$ & $\begin{array}{l}\text { WLWL } \\
(\mathrm{cm})\end{array}$ & $\begin{array}{l}\text { VA } \\
\left({ }^{0}\right) \\
\end{array}$ & SSV & SL & TLF & BLF & $\begin{array}{c}\mathrm{LA} \\
\left(\mathrm{cm}^{2}\right)\end{array}$ & $\begin{array}{l}\mathrm{LS} \\
(\mathrm{cm})\end{array}$ & AR & FF & PR \\
\hline \multirow[t]{3}{*}{1} & $D$ & & & & & & & & & & & & & & \\
\hline & $\begin{array}{l}\text { pentandra, } \\
\text { mean }\end{array}$ & 8.3 & 1.4 & 4.1 & 3.9 & 44.2 & 9.0 & 11.6 & 2.5 & 2.5 & 58.0 & 19.6 & 2.1 & 1.8 & 4.8 \\
\hline & SD & 2.6 & 0.4 & 1.3 & 1.1 & 4.6 & 1.4 & 3.3 & 0.9 & 0.5 & 33.2 & 5.7 & 0.4 & 0.1 & 0.7 \\
\hline \multirow[t]{3}{*}{2} & $M$ & & & & & & & & & & & & & & \\
\hline & $\begin{array}{l}\text { tetragonus, } \\
\text { mean }\end{array}$ & 8.5 & 0.3 & 3.7 & 4.1 & 43.8 & 12.0 & 13.7 & 2.5 & 2.8 & 53.9 & 19.2 & 2.3 & 1.7 & 5.2 \\
\hline & SD & 2.7 & 0.3 & 1.2 & 1.2 & 5.1 & 2.4 & 4.2 & 1.2 & 0.5 & 31.2 & 5.9 & 0.5 & 0.1 & 0.8 \\
\hline
\end{tabular}

Description: LL (lamina length), STL (stalk length), LW (leaf width), WLWL (widest of leaf width length), AV (arch of primer and seconder vein), SSV (sum of secondary vein), SL (sum of leaf), TLF (tip of leaf form), BLF (base of leaf form), LA (leaf area), LS (leaf surrounding), aspcct ratio (AR), form factor (FF), perimeter ratio (PR); $\mathrm{SD}=$ standard deviasi

Table 2. Leaf morphology characteristics V. articulatum

\begin{tabular}{llllllllllll}
\hline $\begin{array}{c}\text { Mistletoe } \\
\text { species }\end{array}$ & $\begin{array}{c}\text { LSC } \\
(\mathrm{cm})\end{array}$ & $\begin{array}{c}\text { LL } \\
(\mathrm{cm})\end{array}$ & $\begin{array}{c}\text { LW } \\
(\mathrm{cm})\end{array}$ & SL & TLF & BLF & $\begin{array}{c}\text { LA } \\
\left(\mathrm{cm}^{2}\right)\end{array}$ & LS & AR & FF & PR \\
\hline $\begin{array}{l}V . \quad \text { articulatum, } \\
\text { mean }\end{array}$ & 2.5 & 2.6 & 0.3 & Many & 4.0 & 1.0 & 1.3 & 4.6 & 9.0 & 0.8 & 15.6 \\
\hline SD & 0.6 & 0.6 & 0.1 & & 4.0 & 1.0 & 0.5 & 1.0 & 2.9 & 0.2 & 4.6 \\
\hline
\end{tabular}

Description: LSC (length of stem section), LL (leaf length), LW (leaf width), SL (sum of leaf), TLF (tip of leaf form), BLF (base of leaf form), LA (leaf area), LS (leaf surrounding), aspcct ratio (AR), form factor (FF), perimeter ratio $(\mathrm{PR}) ; \mathrm{SD}=$ standard deviasi

\section{(2). Identify leaf of morphology characteristic}

Methode of take leaf sample refer to Kremer et al. (2001), with taking one mistletoe plant that has good fenotipe, at least five leaves. Then do identify leaf morfologi more detail, refer to Kremer et al. (2001) with modification of methode Ellis et al. (2009), and Kadir et al. (2012). Variable that will measure and observe for every leaf as follows: lamina lenght, leaf stalk lenght, the widest leaf, the widest leaf to leaf beginning, arch of leaf veins; sum of leaf veins; leaf top form, leaf beginning form; leaf area, leaf surrounding, aspect ratio, form factor, perimeter ratio of diameter.

\section{(3). Collecting basic information of utilization as medicinal plant}

It was analized by comparing the same species of mistletoes on other host trees as reference which was efficacious to be used as medicinal plant.

\section{RESULT AND DISCUSSION}

\section{Identification and description of teak mistletoe species}

According to result plant identification, there was three species teak mistletoes. They were Dendrophthoe pentandra (L.) Miq. include family Loranthaceae, Macrosolen tetragonus (Blume) Miq. include family Loranthaceae, Viscum articulatum Burm.f. include family Santalacea/Viscaceae. Dendropthoe pentandra (L.) Miq., synonyms Loranthus pentandrus L., only Viscum articulatum founded paratizing on other mistletoe are Dendrophthoe pentandra and Macrosolen tetragonus. The description of teak mistletoe based on result of identification of study literature (Backer and Bakhuizen van den Brink 1965), Uji (2007), and verify of field observation as follow: Completed description and usage especially as medicinal plant of $D$. pentandra
(Lemmens and Bunyapraphatsara 2003): Shrub, hemiparasite, rather stiff, many branches, $0.5-1.5 \mathrm{~m}$ tall. Variety of leaves, largely narrow until ellips widely, 6-13 x (1.5-)3-8 cm, petiole $0.5-2 \mathrm{~cm}$ lenght; every inflorescence of 6-12 flowers of raceme, axis 1$2(-3.5) \mathrm{cm}$ lenght, corolla clavate, inflated at lower part, $12-20(-28) \mathrm{mm}$ lenght, tip of obtuse, largely green or yellow - orange, rarely red, tube in flower open (2-)6-12 mm lenght, fruit of ovoid until $0 \times 6 \mathrm{~mm}$. Usage: mush of leaf part to cure pain wound, fester and infektion on skin. Heating water of all part of plant if drink will can cure hipertensi and if mixed of a drink will can cure cough. In Peninsular Malaysia, the leaves are pounded and made into a poultice for treating small sores, ulcers and other skin affections. A decoction of the leaves is administered in Perak (Malaysia) as a protective medicine after childbirth. In Thailand, of D. pentandra or 'Kafak mamuang' an infusion of the dried whole plant is drunk to relieve hypertension. In Vietnam the leaves are mixed with those of regular te to obtain an infusion to enough. Add description of Healthy Ministry of RI (2011), D. pentandra include of 100 medicinal plants. In Laos, Camboja and Vietnam were used to cough medicinal in tea drink, in Malaysia used as cure covery after utter, wound, sore. That mistletoe of chemical ingredient comprises ingredient of flavonoid, fenolat acid (terulat acid, para hidroksi benzoate acid, kumarat acid, protokate acid hard and vanilat acid).

M. tetragonus (Blume) Miq.: Shrub, hemiparasite, rather stiff, many branches. Leaf faced, taper or rather oval, $8-12 \mathrm{~cm}$ length and $3-6 \mathrm{~cm}$ width, thick, leaf base wedge - cut off, leaf stalk $5 \mathrm{~mm}$ length, leaf tip acute until obtuse. Flowering at internode, bunches arranged of $3-9$ flower pairs. Petal of 6 merus, angular, tip cudgel and obtuse, greenish yellow, tube of petal is 6 - $11 \mathrm{~mm}$ length. Anther $1.5-2.5 \mathrm{~mm}$ length and obtuse. 
Usage: until now not known. But compared of usage as medicinal plant of $M$. cochinchinensis (Lour.) $\mathrm{v}$. Tiegh. that in Peninsular Malaysia pounded leaves are used as a poultice to treat headache. The stem juice is drunk to expel the afterbirth. In Indo-China fruits are employed as a cough medicine, and the leaves as a substitute for tea. Compared of M. robinsonii (Gamble) Danser that in Vietnam, the leaves of those are employed to prepare a diuretic tea, specifically to remedy an enlarged abdomen.

$V$. articulatum Burm. F.: Shrub, hemiparasite, slender, stem pendulous 1 metre length, leaves rudimenter, expanding, c. $0.5 \mathrm{~mm}$ length; inflorescence comprises single flower, generally many subsidiary cymules develop around first part, of that female is formed early and those female lateral and male sessile.That male has flower decoration such as 4 cupings, every cuping is short trilateral, $0.25 \mathrm{~mm}$ length. The female of cuping achieves $0.5 \mathrm{~mm}$ length that fewer short than tube and rather thick.; fruit globose, fine, white.

Usage: Stew all part of plant, if drink it will can cure bronchitis. Besides can use too as aprodisiak and neuralgik and cure skin of tumor and anthritis. In Cambodia a decoction of $V$. articulatum is prescribed for the treatment of bronchitis. It is credited with tonic and sedative properties. In India it is used as an aphrodisiae and febrifuge, and to treat skin tumours. Apoultice of crushed stems is applied to cuts. In Taiwan the whole plant is used as aremedy for neuralgia. In China whole plants are used to treat arthritis.

\section{Leaf morphology characteristics}

Measure result of leaf morphology characteristics $D$. pentandra $(\mathrm{n}=62)$ and $M$. tetragonus $(\mathrm{n}=37)$ both include family Loranthaceae, as illustrated at Table 1.

That $V$. articulatum $(\mathrm{n}=20)$ include family Viscacea, has leaf rudimenter and look like small bractea so only some leaf morphology characteristics can measure as illustrated at Table 2 .

\section{ACKNOWLEDGEMENTS}

The authors thank to Development and Research Center Perhutani for permitting on research location and facilitate so this research can well done.

\section{REFERENCES}

Backer CA, RC Bakhuizen van den Brink. 1965. Flora of Java Vol. 2. Noordhoff, Groningen, The Netherlands, 67-76.

Development and Research Center Perhutani. 2012. Evaluation report of mistletoe attacking in CSO teak in Padangan. Cepu.

Development and Research Center Perhutani. 2013a. Evaluation report of mistletoe attacking in CSO teak in Randublatung and Cepu. Cepu.

Development and Research Center Perhutani. 2013b. Data of sum of tree that attacking mistletoe in CSO Padangan (result of inventory on October 2013). Cepu.

EFForTS/CRC990. 2012. Brief Report (still under improvement) Field Trip-Jambi (12-17 Oktober 2012). Jambi

Ellis B, Douglas CD, Leo JH, Kirk RJ, John DM, Peter W, Scott LW. 2009. Manual of leaf architecture. United States of Amerika (US): Cornell University Pr.

Healthy Ministry of RI. 2011. 100 top of medicinal plant Indonesia. Large office of Development and Research medicinal plant and of traditional, Healthy Ministry of RI. Tawangmangu.

Kadir A, Lukito E, Adhi S, Insap S. 2012. Experiments of Zernike moments for leaf identification. Journal of Theoretical and Applied Inform Tech. 41(1):82-93.

Kremer A, Dupouey J, Deans J, Cottrell J, Csaikl U, Finkeldey R, Espinel S, Jensen J, Kleinschmit J, Barbara Van Dam. 2001. Leaf morphological differentiation between Quercus robour and Quercus petraea is stable across Western European mixed oak stands. J For Sci. 59:777787.

Lemmens RHMJ and Bunyapraphatsara N. (Editors). 2003. Plant Resources of South-East Asia 12(3) Medicinal and poisonous plants 3. PROSEA Foundation, Bogor, Indonesia. $664 \mathrm{pp}$

Muttaqin Z. 2014. Character biology of teak mistletoe in CSO Padangan, Regional Division East Jawa of Perum Perhutani [PhD thesis Draft]. Bogor (ID): Bogor Agriculture University.

Uji T. 2007. Technical report of diversity mistletoe plant species in Botanical garden of Cibodas, West Java. Biology research center LIPI. Bogor. 